\title{
FOOD SECURITY OF THE POPULATIONS OF THE COMMUNE OF GOGOUNOU IN BENIN: CONTRIBUTION OF EDIBLE PLANT NATURAL RESOURCES
}

\author{
Nadiatou BOUKARY IBRAHIM ${ }^{1,2,3}$; Paulin Jésutin DOSSOU ${ }^{1,3}$ and Boni SOUNON BOUKO ${ }^{1,2}$ \\ ${ }^{1}$ Department of Geography and Spatial Planning, University of Parakou, Benin \\ ${ }^{2}$ Doctoral School of Agronomic and Water Sciences, University of Parakou \\ ${ }^{3}$ Laboratory of Ecology, Botany and Plant Biology of the University of Parakou
}

https://doi.org/10.35410/IJAEB.2021.5688

\begin{abstract}
Natural edible plant resources permit rural populations to assure their food. However, the contribution of these resources to the food security of the populations is unknown. The objective of this study is to determine the contribution of edible natural plant resources to food security. The data collection methods used are socio-economic interviews, household visits and collecting geographical data of natural plant resources that are present in the nature. Data analysis made manually with the Excel sheet and the evaluation method of consumption score of (FAO, 2014). The results obtained show that there are forty (40) principal natural plant resources that exist seasonally and that contribute to food for populations. The consumption score of these resources is acceptable (72\%). The frequency of consumption varies from 2 to 4 times daily, weekly and annually for resources that are difficult to access. As for appreciation of these resources, it is very good for most of people surveyed, because they find satisfaction after consumption. Edible mushrooms contribute significantly to the nutritional value and protein. They substitute meat during availability periods. Some preservation technics have been proposed to guarantee the food in full-time through of these resources nnconsumption.
\end{abstract}

Keywords: Benin - Gogounou - Edible plant natural resources - food security - food diversity.

\section{INTRODUCTION}

Plant formations in Benin represent a potential source of edible resources (C. Goussanou etal., 2010, p. 77). These resources are consumed as a staple or main course, supplementary food, binder, condiments or as aromatics, stimulants or aphrodisiacs, appetizers (FAO, p.29). Wild plant resources globally play a crucial role in many food systems that improve the resilience of the food system and the diversity and quality of food (A. Daudet, 2012, p.11). Thus, meeting the food needs of populations is a major problem facing most Sahel countries (D. I. Moussa et al.,2020, p. 328). Of the more than 50,000 edible plant species in the world, only a few hundred contribute significantly to food availability. Among these plant resources, fruits and leaves are of great importance in the diet of populations and contribute to food security. Fruits are rich in vitamins, minerals and provide protein, energy, iron and carbohydrates to children aged 24 to 59 months (F. Alladayé et al., 2017, p.54 ). Edible mushrooms are part of the edible natural plant resources and consist of a food value comparable with that of vegetables; some authors consider them as a kind of "vegetable meat" (FAO, 2006, P. 2). The commune of Gogounou is a rural environment that is full of several natural plant resources that are exploited very frequently in the diet of the populations. These resources collected in various places (forests, fields, fallow, 
courtyard edges, etc.) are consumed as fruits, vegetables, processed into juice or used for agrifood processing, etc. Thus, these resources rich in vitamins, iron, mineral salts, energies, etc. make it possible to balance and strengthen the food security of populations. This study makes it possible to determine the contributions of edible natural plant resources to the food security of populations.

\section{MATERIALS AND METHODS}

\subsection{Study Environment}

The commune of Gogounou is located in the extreme south of the department of Alibori. It is bounded to the north by the Communes of Banikoara and Kandi; to the south by Sinendé and Bembèrèkè; to the east by Ségbana and Kalalé; then to the west by Kérou and covers an area of $4910 \mathrm{~km}^{2}$. It is divided into six arrondissements and thirty-four villages and town districts distributed as follows: Gogounou (4 districts), Bagou (10 villages), Gounarou (4 villages), Zougou-Pantrossi (4 villages), Sori (8 villages), Wara (4 villages).

The commune of Gogounou is made up of protected areas, shallows and rivers. The gallery forests that develop along the rivers promote the development of edible natural plant resources, basic sauces of the populations. The availability of these resources contributes to the strengthening of food and household food security. Natural plant resources contain various nutrients that allow the supply of vitamins, minerals, etc. Its population in 2013 (RGPH 4) is 117523 inhabitants. Figure 1 shows the geographical location of the commune of Gogounou.

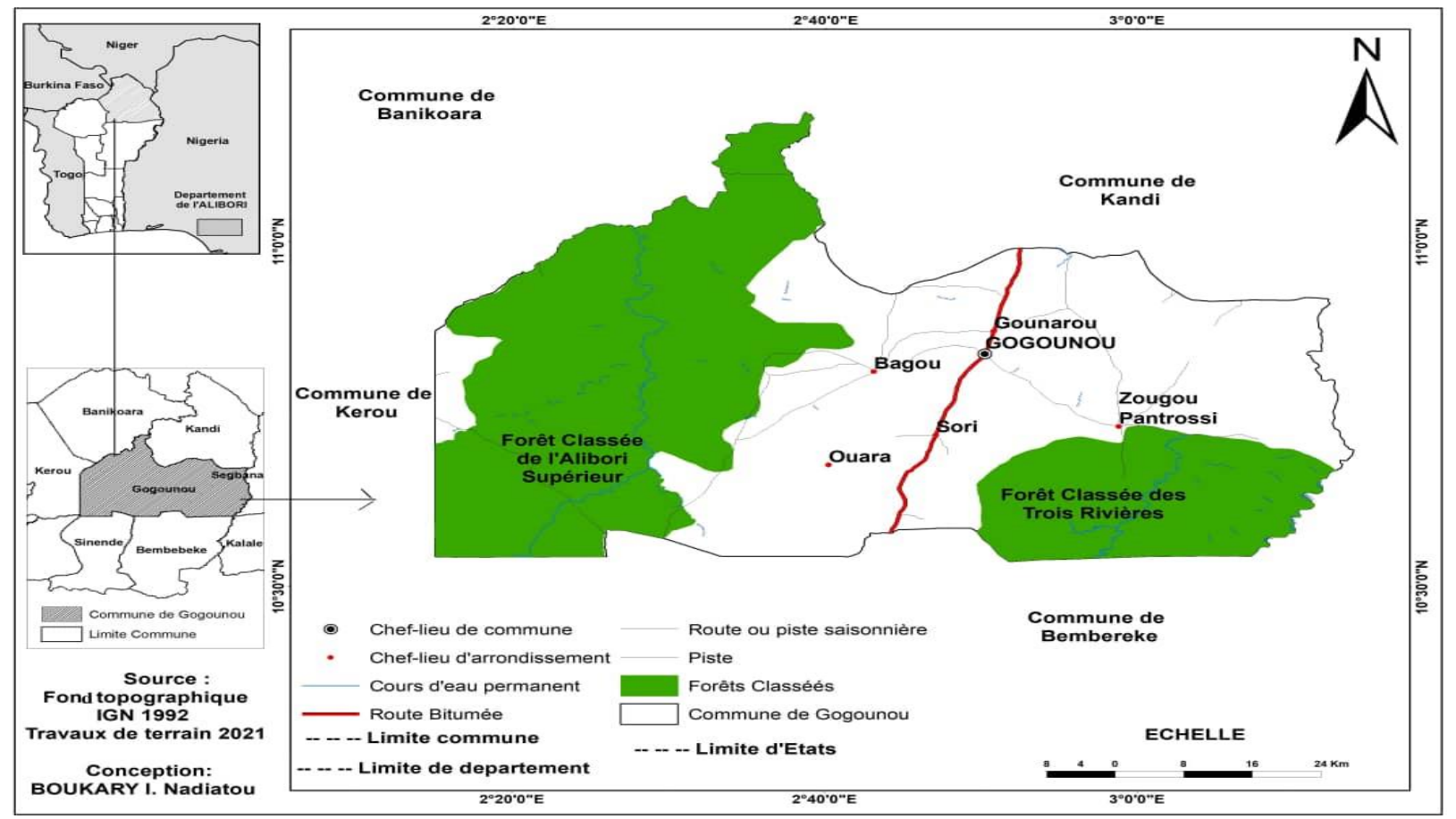

Figure 1: Geographical location of the commune of Gogounou 
Vol. 06, No. 06; 2021

ISSN: $2456-8643$

\subsection{Collection Method}

Socio-economic surveys were conducted for data collection. The targeted individuals are households and sellers of edible plant natural resources. Households have been taken into account because edible natural plant resources are consumed in households and women are collectors of these resources. The geographical coordinates of the resources were taken at the level of the municipality in order to establish the distribution map of these resources. The stay in the households made it possible to see the frequency and diversification of resources over the course of a day, or even a week. All six districts of the commune have been visited. These are the district of Gogounou centre, Sori, Gounarou, Bagou, Ouara and Zougou Pantrossi. The districts that are closer to the classified forests of the three rivers and the upper Alibori have the largest number of people surveyed. This will make it possible to see if their proximity to these forests promotes access to and massive consumption of edible natural plant resources.

\section{Sampling}

The sample size was calculated using the method of (Dagnelie, 1998).

$$
n=\frac{U_{1-\frac{\alpha}{2}}^{2} \times{ }^{P(1-P)}}{d^{2}} \text { with }
$$

$\mathrm{n}=$ sample size;

$U_{1-\frac{\alpha}{2}}^{2}=1.96$ : this is the $95 \%$ confidence level of the random normal variable;

$\mathrm{P}$ is the proportion of individuals who consume edible natural plant resources; the p-value was determined by taking $70 \%$ as the proportion of populations consuming edible plant natural resources. Let $\mathrm{p}=0.7$

$\mathrm{d}$ : is the margin of error at the $5 \%$ threshold; $\mathrm{d}=0.05$

$n=\frac{1,96 \times 0,7(1-0,7)}{(0,05)^{2}}$

A total of 165 people were surveyed, spread over the different localities of the six districts visited.

\subsection{Method of analysis}

Data from socio-economic household surveys with Kobo collect software were exported in spreadsheet format (Excel) and analyzed. To determine the contribution of edible plant natural resources to food security, several parameters were assessed. It is the availability of resources through a distribution map, the diversity and frequency of consumption of resources over a given period or time. Diversity was determined through a score called the Dietary Diversity Score (SDA). Access to food is assessed from the Food Consumption Score (SCA). The diversity and frequency of consumption were assessed through the answer to the question: "How many times do you consume at least one plant resource per day or per week?". 
Table 1: Food Consumption Score Assessment

\begin{tabular}{|l|l|lr|}
\hline \multicolumn{2}{|l|}{$\begin{array}{l}\text { Consumption score } \\
\text { food (SCA) }\end{array}$} & Interpretation \\
\hline Poor & $<21(<28)$ & $\begin{array}{l}\text { Inadequate quantity and } \\
\text { quality }\end{array}$ \\
\hline Limit & $\begin{array}{l}21.5-35(28.5 \text { to } \\
42)\end{array}$ & $\begin{array}{l}\text { Inadequate quality } \\
\text { (quantity?) }\end{array}$ \\
\hline $\begin{array}{l}\text { Acceptabl } \\
\mathrm{e}\end{array}$ & $>35(>42)$ & Adequate diet (?) & \\
\hline
\end{tabular}

Source FAO, 2014

\section{RESULTS AND DISCUSSION}

\subsection{Results}

3.1.1 Availability of edible plant natural resources

The edible natural plant resources identified by the populations and which enter their diet are composed of leaves, fruits, roots, tubers, roots, bark, seed/nuts, pulp, and edible mushrooms. These resources collected in nature on various sites (fields, fallows, river edges, forests, savannahs, dead woods, termite mounds, etc.) are available according to the seasons and according to each resource. Leaf resources that are consumed in vegetable or slimy sauces are much more available in the rainy season. Fruits are much more available during the dry season. As for mushrooms, their availability is only in the rainy season and extends from April to June. Figure 2 shows the distribution map of edible plant natural resources.

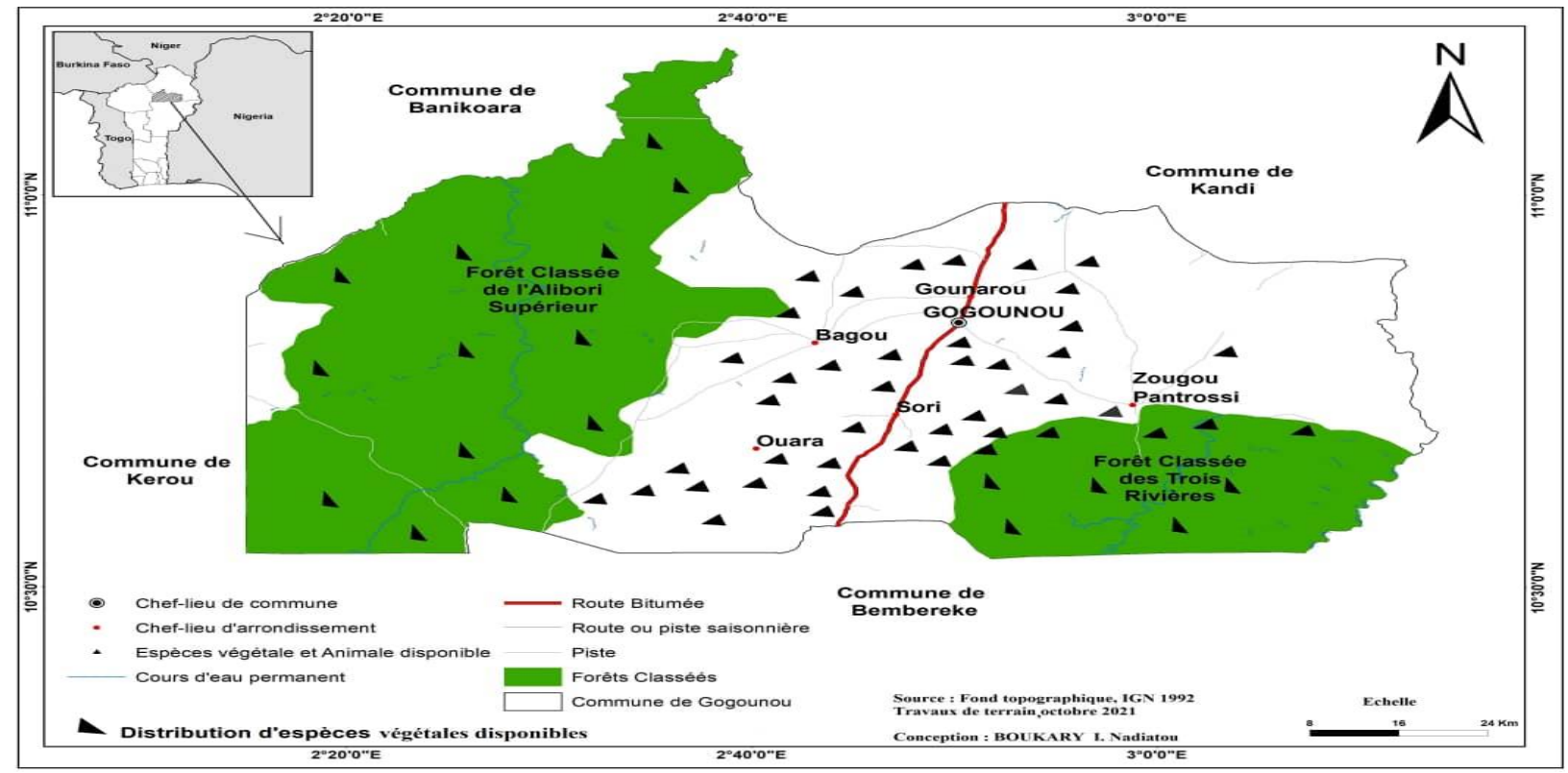

Figure 2: Distribution of natural plant resources consumed in Gogounou

Source: Tavaux de terrain 


\subsubsection{Seasonal Availability of Edible Natural Plant Resources}

A total of 40 plant resources for food consumption have been identified in the commune of Gogounou. These resources are classified into several types namely: vegetables, roots, fruits, bark and pulp and edible mushrooms. The availability of these resources varies from season to season. Some resources are available full-time, others in the rainy season and another group in the dry season. As for edible mushrooms the period availability of these mushrooms is only in the rainy season. Table 2 presents the edible natural plant resources identified and the periods of availability.

Table 2: Period of Availability of Edible Natural Plant Resources

\begin{tabular}{|l|l|l|l|l|}
\hline No & $\begin{array}{l}\text { Local name of the } \\
\text { species (Baatonu, } \\
\text { Peulh, Yom, Nagot) }\end{array}$ & $\begin{array}{l}\text { Scientific name of the } \\
\text { species }\end{array}$ & $\begin{array}{l}\text { Parts } \\
\text { consumed }\end{array}$ & $\begin{array}{l}\text { Availabili } \\
\text { ty period }\end{array}$ \\
\hline $\mathbf{1}$ & Baba shop & $\begin{array}{l}\text { Annona Senegalencis } \\
\text { Press., } 1806\end{array}$ & Fruits & Full-time \\
\hline $\mathbf{2}$ & Banru & $\begin{array}{l}\text { Borassus aethiopum Mart., } \\
\text { 1838 }\end{array}$ & Fruits & $\begin{array}{l}\text { Dry } \\
\text { season }\end{array}$ \\
\hline $\mathbf{3}$ & Bireru & $\begin{array}{l}\text { Saba comorensis (Bojer ex } \\
\text { ADC.) Pichon, 1953 }\end{array}$ & Fruits & $\begin{array}{l}\text { Dry } \\
\text { season }\end{array}$ \\
\hline $\mathbf{4}$ & bonsindu & $\begin{array}{l}\text { Termitomyces letestui De } \\
\text { Kesel 2002 }\end{array}$ & $\begin{array}{l}\text { Whole } \\
\text { plant }\end{array}$ & $\begin{array}{l}\text { Rainy } \\
\text { season }\end{array}$ \\
\hline $\mathbf{5}$ & We will say & $\begin{array}{l}\text { Blighia sapida K.D. Koenig, }, \\
\text { 1782 Fruits }\end{array}$ & $\begin{array}{l}\text { Dry } \\
\text { season, } \\
\text { Rainy } \\
\text { season }\end{array}$ \\
\hline $\mathbf{6}$ & House & $\begin{array}{l}\text { Parkia biglobosa (Jacq.) } \\
\text { R.Br. ex G.Don, 1830 }\end{array}$ & $\begin{array}{l}\text { Fruits, } \\
\text { pulp }\end{array}$ & $\begin{array}{l}\text { Rainy } \\
\text { season }\end{array}$ \\
\hline $\mathbf{7}$ & Ganou & Ficus thonningii & Fruits & $\begin{array}{l}\text { Rainy } \\
\text { season }\end{array}$ \\
\hline $\mathbf{8}$ & Ganyérou & $\begin{array}{l}\text { Sarcocephalus latifolius } \\
\text { (Sm.) E.A.Bruce, 1947 }\end{array}$ & $\begin{array}{l}\text { Fruits, } \\
\text { root }\end{array}$ & $\begin{array}{l}\text { Rainy } \\
\text { season }\end{array}$ \\
\hline $\mathbf{9}$ & Gbêssênou & $\begin{array}{l}\text { Detarium microcarpum } \\
\text { Guill. Et Perr., 1832 }\end{array}$ & Fruits & $\begin{array}{l}\text { Dry } \\
\text { season }\end{array}$ \\
\hline $\mathbf{1 0}$ & geïngi, sunundu or & $\begin{array}{l}\text { Lactarius gymnocarpoides } \\
\text { De Kesel et al, 2002 }\end{array}$ & $\begin{array}{l}\text { Whole } \\
\text { plant }\end{array}$ & $\begin{array}{l}\text { Rainy } \\
\text { season }\end{array}$ \\
\hline
\end{tabular}


International Journal of Agriculture, Environment and Bioresearch

Vol. 06, No. 06; 2021

ISSN: $2456-8643$

\begin{tabular}{|c|c|c|c|c|}
\hline 11 & $\begin{array}{l}\text { Gnanra would be a } \\
\text { fan }\end{array}$ & $\begin{array}{l}\text { Amaranthus tricolor L., } \\
1753\end{array}$ & Leaves & $\begin{array}{l}\text { Rainy } \\
\text { season }\end{array}$ \\
\hline 12 & Gnanra gninon & $\begin{array}{l}\text { Combretum micranthum } \\
\text { G.Don, } 1824\end{array}$ & Leaves & $\begin{array}{l}\text { Rainy } \\
\text { season }\end{array}$ \\
\hline 13 & Gnanra yinon kpiga & $\begin{array}{l}\text { Senna obtusifolia }(\text { L.) } \\
\text { H.S.Irwin and Barneby, } \\
1982\end{array}$ & Leaves & $\begin{array}{l}\text { Rainy } \\
\text { season }\end{array}$ \\
\hline 14 & Gourokou & Ximenia americana L., 1753 & Fruits & $\begin{array}{l}\text { Dry } \\
\text { season }\end{array}$ \\
\hline 15 & itikwaje or bubidji & $\begin{array}{l}\text { Termitomyces clypeatus De } \\
\text { Kesel } 2002\end{array}$ & $\begin{array}{l}\text { Whole } \\
\text { plant }\end{array}$ & $\begin{array}{l}\text { Rainy } \\
\text { season }\end{array}$ \\
\hline 16 & Kireba & Rubinoboletus sp. & $\begin{array}{l}\text { Whole } \\
\text { plant }\end{array}$ & $\begin{array}{l}\text { Rainy } \\
\text { season }\end{array}$ \\
\hline 17 & Kounonkou & Vitex doniana, Sweet, 1827 & $\begin{array}{l}\text { Fruits, } \\
\text { leaves }\end{array}$ & $\begin{array}{l}\text { Dry } \\
\text { season } \\
\text { Rainy } \\
\text { season }\end{array}$ \\
\hline 18 & Kpararou & $\begin{array}{l}\text { Cochlospermum tinctorium } \\
\text { Perr. ex A. Rich., } 1831\end{array}$ & Root & Full-time \\
\hline 19 & Kpé wonka & Solanum nigrum L., 1753 & Leaves & $\begin{array}{l}\text { Rainy } \\
\text { season }\end{array}$ \\
\hline 20 & Lodjun & Lepista sp. The Kesel 2002 & $\begin{array}{l}\text { Whole } \\
\text { plant }\end{array}$ & $\begin{array}{l}\text { Rainy } \\
\text { season }\end{array}$ \\
\hline 21 & Mossosso & $\begin{array}{l}\text { Tamarinthus indicaS L., } \\
1753\end{array}$ & Fruits & $\begin{array}{l}\text { Dry } \\
\text { season }\end{array}$ \\
\hline 22 & Njékudjéol & $\begin{array}{l}\text { Amanita strobilaceovolvata } \\
\text { Beeli (1935) }\end{array}$ & $\begin{array}{l}\text { Whole } \\
\text { plant }\end{array}$ & $\begin{array}{l}\text { Rainy } \\
\text { season }\end{array}$ \\
\hline 23 & Nopimusu & $\begin{array}{l}\text { Termitomyces medius De } \\
\text { Kesel } 2002\end{array}$ & $\begin{array}{l}\text { Whole } \\
\text { plant }\end{array}$ & $\begin{array}{l}\text { Rainy } \\
\text { season }\end{array}$ \\
\hline 24 & $\begin{array}{l}\text { osusu égini ou ese } \\
\text { adie }\end{array}$ & $\begin{array}{ll}\text { Cantharellus } & \text { floridulus } \\
\text { Heinem. (1958) } & \end{array}$ & $\begin{array}{l}\text { Whole } \\
\text { plant }\end{array}$ & $\begin{array}{l}\text { Rainy } \\
\text { season }\end{array}$ \\
\hline 25 & osusu éla & $\begin{array}{l}\text { Russula pseudopurpurea, } \\
\text { Yorou et De Kesel } 2002\end{array}$ & $\begin{array}{l}\text { Whole } \\
\text { plant }\end{array}$ & $\begin{array}{l}\text { Rainy } \\
\text { season }\end{array}$ \\
\hline
\end{tabular}


International Journal of Agriculture, Environment and Bioresearch

Vol. 06, No. 06; 2021

ISSN: $2456-8643$

\begin{tabular}{|c|c|c|c|c|}
\hline 26 & osusu émé & $\begin{array}{l}\text { Macrocybe lobayensis De } \\
\text { Kesel } 2002\end{array}$ & $\begin{array}{l}\text { Whole } \\
\text { plant }\end{array}$ & $\begin{array}{l}\text { Rainy } \\
\text { season }\end{array}$ \\
\hline 27 & Palidji & $\begin{array}{l}\text { Psathyrella tuberculata De } \\
\text { Kesel } 2002\end{array}$ & $\begin{array}{l}\text { Whole } \\
\text { plant }\end{array}$ & $\begin{array}{l}\text { Rainy } \\
\text { season }\end{array}$ \\
\hline 28 & Poura porou & $\begin{array}{ll}\text { Calotropis } & \text { procera } \\
\text { W.T.Aiton, } 1811 & \end{array}$ & Leaves & Full-time \\
\hline 29 & San Moor & Spondias mombin L., 1753 & Fruits & $\begin{array}{l}\text { Rainy } \\
\text { season }\end{array}$ \\
\hline 30 & Sombu & $\begin{array}{l}\text { Vitellaria } \\
\text { C.F.Gaertn., } 1807\end{array}$ & Fruits & $\begin{array}{l}\text { Rainy } \\
\text { season }\end{array}$ \\
\hline 31 & Rang & Adansonia digitata L., 1759 & $\begin{array}{l}\text { Fruits, } \\
\text { pulp, } \\
\text { leaves }\end{array}$ & Full-time \\
\hline 32 & Presented & $\begin{array}{l}\text { Octaviania } \\
\text { Kesel } 2002\end{array}$ & $\begin{array}{l}\text { Whole } \\
\text { plant }\end{array}$ & $\begin{array}{l}\text { Rainy } \\
\text { season }\end{array}$ \\
\hline 33 & Sunundu & $\begin{array}{l}\text { Lactarius } \\
\text { pseudogymnocarpus } \\
\text { Verbeken } 1995\end{array}$ & $\begin{array}{l}\text { Whole } \\
\text { plant }\end{array}$ & $\begin{array}{l}\text { Rainy } \\
\text { season }\end{array}$ \\
\hline 34 & takuntarudji or gun & $\begin{array}{l}\text { Marasmius spp. The Kesel } \\
2002\end{array}$ & $\begin{array}{l}\text { Whole } \\
\text { plant }\end{array}$ & $\begin{array}{l}\text { Rainy } \\
\text { season }\end{array}$ \\
\hline 35 & $\begin{array}{ll}\text { tokomintau } & \text { or } \\
\text { takuntarudji } & \end{array}$ & $\begin{array}{ll}\text { Lentinus } & \text { squarrosulus } \\
\text { Mont. } 1842 & \end{array}$ & $\begin{array}{l}\text { Whole } \\
\text { plant }\end{array}$ & $\begin{array}{l}\text { Rainy } \\
\text { season }\end{array}$ \\
\hline 36 & Turokuradi & $\begin{array}{l}\text { Amanita crassiconus De } \\
\text { Kesel et al. }(2002)\end{array}$ & $\begin{array}{l}\text { Whole } \\
\text { plant }\end{array}$ & $\begin{array}{l}\text { Rainy } \\
\text { season }\end{array}$ \\
\hline 37 & Wari & $\begin{array}{ll}\text { Ceratotheca } & \text { sesamoides } \\
\text { Endl } 1832 & \end{array}$ & Leaves & Full-time \\
\hline 38 & Winbou & $\begin{array}{l}\text { Diospyros mespoliformis } \\
\text { Hochst. Ex A.DC., } 1844\end{array}$ & Fruits & $\begin{array}{l}\text { Dry } \\
\text { season }\end{array}$ \\
\hline 39 & Yirou guiya & $\begin{array}{l}\text { Gardenia erubescens Stapf } \\
\text { et Hutch., } 1909\end{array}$ & Fruits & $\begin{array}{l}\text { Dry } \\
\text { season }\end{array}$ \\
\hline 40 & Yoronou or Yodou & Lannea acida L., 1753 & Fruits & $\begin{array}{l}\text { Rainy } \\
\text { season }\end{array}$ \\
\hline
\end{tabular}


Source: Fieldwork, 2021, De Souza S., 1988, Yorou and De Kesel et al., 2002, Mont. 1842, Verbeken, 1995, Lepista sp., 2002, Beeli (1935)

Table 2 shows that fruits $(42.5 \%)$ and mushrooms $(40 \%)$ are the most consumed among the resources identified by the populations. The leaves $(20 \%)$ come in the third plane. Then come the other parts consumed (root (5\%) and pulp (5\%)). Fruits are much more available at $70 \%$ in the dry season, $25 \%$ in the rainy season and $5 \%$ in full-time. The consumed leaves are available $75 \%$ in the rainy season, $15 \%$ in the dry season and $10 \%$ in full-time. As for the pulp, it is available in the dry season and the roots in full time. Mushrooms are available at the beginning of the rainy season $(70 \%)$ until June $(30 \%)$. The rainy season is therefore the period of abundance of vegetable plant resources and the dry season the period of abundance of fruits. The latter is the lean season when many resources are scarce. The only resources that populations manage to conserve in dried forms are often consumed during this period. These are: Blighia sapida, Adansonia digitata, Ceratotheca sesamoides, Vitellaria paradoxa (transformed into butter), Parkia biglobosa (transformed into a motorcyclist), Tamarinthus indica, Cochlospermum tinctorium and Vitex doniana. Among these resources consumed during the lean season, Vitex doniana is only consumed during this period. During this period, edible mushrooms complement vegetable plant resources. The population estimates the consumption of its leaves in the rainy season as vectors of intestinal worms to the human organism. Tamarinthus indica is also much more consumed in dry periods because the consumption of its fruits allows to release toxins from the body through frequent urine.

\subsubsection{Diversity and frequency of consumption of edible plant natural resources}

Dietary diversity represents the number of different natural plant resources consumed during a given period ranging from one day to 7 days. The frequency of consumption of edible plant natural resources varies from person to person and from occupation to occupation. Agricultural households top the list of those that consume more natural plant resources. This is because women are collectors of these resources and they regularly frequent the sites where the resources are located. Traders come in second place because it stays in touch with the sellers of these resources and they are the first people to see the arrival of resources on the market.

As for mushrooms, the frequency of consumption varies from a daily consumption (once or twice a day), 4 to 6 times / week, 2 to 4 times / week and 1 time / week. Figure 3 shows the frequency of consumption of edible plant natural resources. 


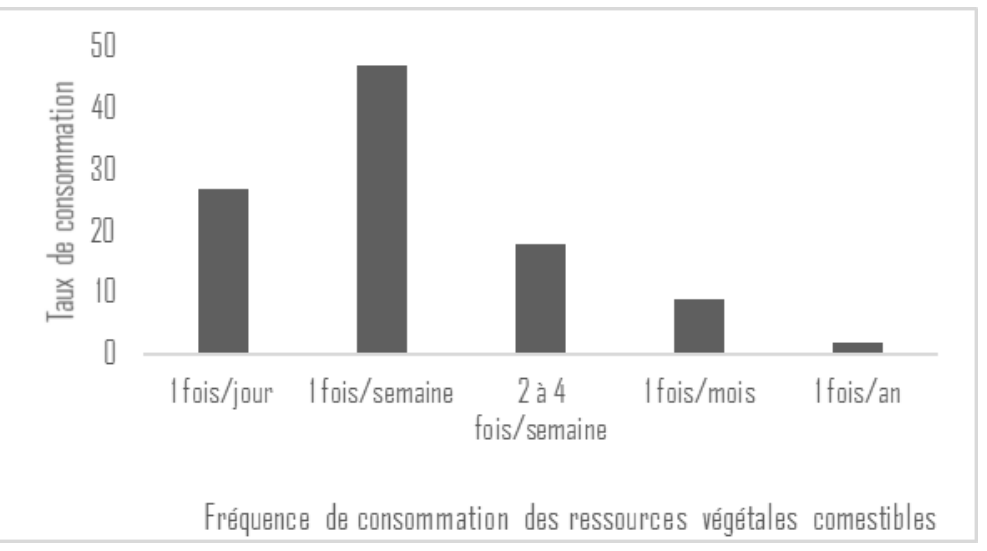

Figure 3: Frequency of consumption of edible plant natural resources by households

Source: Fieldwork, 2021

Figure 3 shows that the frequency of resource consumption varies from once a year to 2 to 4 times a day. It should be noted that the frequency of consumption also varies according to the season of availability. The resources that are consumed once a year are usually fruits whose access is a little difficult and mushrooms that are available on an ad hoc basis. These are the fruits whose collection requires a lot of physical effort and usually it is the men who make the collection. These are Saba comorensis and Ximenia americana. The resources that are consumed 2 to 4 times / day are generally leaves, roots and products from the processing of certain resources including shea butter from Vitellaria paradoxa and motorcyclists from Parkia biglobosa. The latter are used in almost all daily household meals. Cochlospermum tinctorium is also a basic resource in the preparation of the sauce. The powder of these roots is used instead of tomato and accompanies all meals.

\subsubsection{Consumption score of edible plant natural resources}

Diversifying food consumption is a key step towards food security. This diversity of food consumption is measured by the food consumption score. For the calculation of this score, 5 edible plant resource food groups were considered. Next, a table was created indicating the frequencies, estimated in number of days, of consumption of each food group. Each food group has a qualitative weighting factor that reflects its nutritional value. This weighting factor is based on the density of nutrients contained in the food consumed. The consumption frequencies of each weighted and summed food group constitute the Food Consumption Score (FCS) determined for each household (WFP, 2013, P.37).

Table 3: Edible Plant Resources Consumption Score

\begin{tabular}{|l|l|l|l|lr|l|}
\hline $\begin{array}{l}\text { Group of } \\
\text { plant } \\
\text { resources } \\
\text { consumed }\end{array}$ & $\begin{array}{l}\text { Associated for } \\
\text { foods } \\
\text { consumption in } \\
\text { the household }\end{array}$ & $\begin{array}{l}\text { Weighting } \\
\text { coefficient }\end{array}$ & Justification & $\begin{array}{l}\text { Number of } \\
\text { days } \\
\text { consumption } \\
\text { in a week }\end{array}$ & $\begin{array}{l}\text { Score by } \\
\text { resource } \\
\text { group } \\
\text { consumed }\end{array}$ \\
\hline
\end{tabular}




\begin{tabular}{|c|c|c|c|c|c|}
\hline Vegetables & $\begin{array}{l}\text { Sauce, rice, } \\
\text { dough, crushed } \\
\text { yam }\end{array}$ & 4 & \multirow{5}{*}{$\begin{array}{l}\text { Low in } \\
\text { energy and } \\
\text { protein, no } \\
\text { fat, rich in } \\
\text { micronutrient } \\
\text { s. }\end{array}$} & 7 & 28 \\
\hline Fruits & $\begin{array}{ll}\begin{array}{l}\text { Fruits, } \\
\text { juice }\end{array} & \text { fruit } \\
\end{array}$ & 4 & & 2 & 8 \\
\hline Pulp & Fruit juice & 4 & & 1 & 4 \\
\hline Root & $\begin{array}{l}\text { Sauce, herbal } \\
\text { tea }\end{array}$ & 3 & & 4 & 12 \\
\hline Bark & Decoction & 2 & & 2 & 4 \\
\hline $\begin{array}{l}\text { Edible } \\
\text { mushrooms }\end{array}$ & Sauce & 4 & $\begin{array}{l}\text { Protein, fat, } \\
\text { carbohydrates } \\
\text { (glucose, } \\
\text { sucrose), } \\
\text { energy value, } \\
\text { vitamins, } \\
\text { minerals, } \\
\text { trace } \\
\text { elements }\end{array}$ & 4 & 16 \\
\hline \multicolumn{5}{|c|}{ Consumption score of edible plant resources } & 72 \\
\hline
\end{tabular}

Source: Fieldwork, 2021, WFP, 2013

Score $<28=$ Low food consumption

Score between 28.5 and $42=$ Food consumption limit

Score between > 42. Acceptable food consumption

Table 3 shows that the consumption score for edible plant natural resources is acceptable (score $=72$ ). This value explains the contribution of edible plant natural resources to food security. They therefore occupy an important place in the diet of populations by massive intake of micronutrients.

\subsubsection{Appreciation of edible plant natural resources}

The edible natural plant resources consumed in Gogounou are appreciated according to the organ. In general, fruits are more appreciated by the populations because they are directly consumed or sometimes transformed into juice. As for vegetables, they come in second place of appreciation. Cochlospermum tinctorium is a resource whose root powder is highly appreciated by the population because of its very succulent taste in the sauce and the nutrients it contains. Edible mushrooms are very well appreciated by the populations by their contributions of protein, 
fat, carbohydrate, vitamin, mineral salts, etc. The leapand availability of these mushrooms during the collection period means that people prefer the consumption of these mushrooms. Indeed, these edible mushrooms have an excellent taste than vegetable resources. They are therefore compared to meat because of their taste. During the period of availability of these mushrooms, the concerns of the populations for the supply of meat decrease. They use edible mushrooms instead of protein products.

Figure 4 presents the assessment of the edible natural plant resources consumed by the populations of Gogounou.

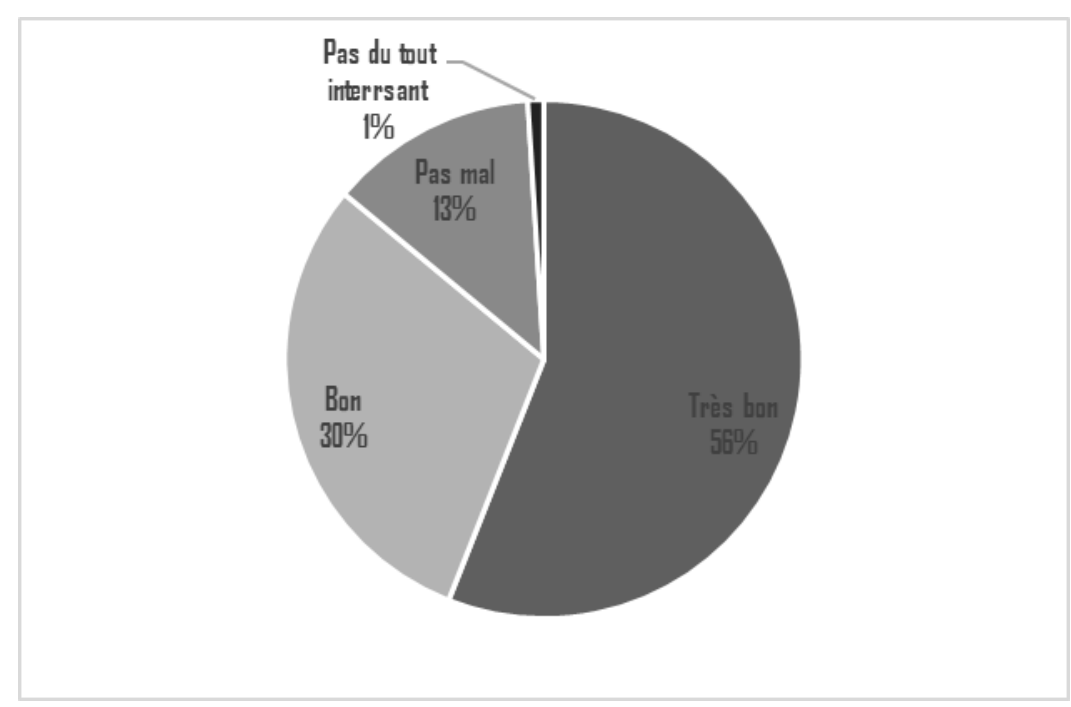

Figure 4: Taste appreciation of edible plant resources

Source: Fieldwork, 2021

Figure 4 shows that $56 \%$ of the populations surveyed give a very good appreciation to resources $30 \%$ good, $13 \%$ not bad and $1 \%$ not at all interesting. Table 4 presents the nutritional values of edible mushrooms in the diet. These values have been determined by some authors including: Degreef, 1992; Yorou and De Kesel, 2001; Courtecuisse and Duhem, 1994.

Table 4: Nutritional Values of Edible Mushrooms

\begin{tabular}{|l|l|}
\hline Elements & Value \\
\hline Water & of the order of $90 \%$ \\
\hline Protein & $+/-50 \%$ of dry weight \\
\hline Fat & Between $2 \%$ and $8 \%$ of dry weight \\
\hline $\begin{array}{l}\text { Carbohydrates } \\
\text { sucrose) }\end{array}$ & + glucose $50 \%$ of dry weight \\
\hline Energy value & of the order of 35 Kcal per 100 grams \\
\hline
\end{tabular}


Vol. 06, No. 06; 2021

ISSN: $2456-8643$

\begin{tabular}{|l|l|}
\hline Vitamins & $\begin{array}{l}\text { B (thiamine, niacin and riboflavin) } \\
\text { - Ergosterol (vitamin D precursor) Folic acid (necessary } \\
\text { for the development of the nervous system of fetuses) } \\
\text { - Carotene } \\
\text { - Pannonic acid }\end{array}$ \\
\hline Minerals & $\begin{array}{l}\text { - Phosphorus } \\
\text { - Potash }\end{array}$ \\
\hline Trace elements & Copper, Selenium, Zinc, Aluminum iron \\
\hline
\end{tabular}

Source : Degreef, 1992 ; Yorou \& De Kesel, 2001 ; Courtecuisse \& Duhem, 1994.

\subsubsection{The role of edible plant natural resources in food security}

The contribution of edible plant resources is determined through their availability, accessibility and use. Stability was not addressed in this study.

The seasonal availability of plant resources allows the population of Gogounou to diversify their diet according to the period. Some resources are even intended only for the lean season. Populations manage to diversify their diet 2 to 4 times over a period of 7 days into leafy vegetables, fruits, fruit juices and edible mushrooms. The study showed that edible natural plant resources conserved in dry forms contribute massively to household nutrition during the lean season. The plant resource consumption score is acceptable. This means that these resources contribute to strengthening food security. In terms of accessibility and use, people have physical access to resources. This facilitates the collection and consumption of these edible natural plant resources.

\section{DISCUSSION}

The study showed that the availability of edible natural plant resources consumed in Gogounou allows people to diversify their diet during the year. These products make it possible to reinforce the contribution of cultivated products that break at a time of year. This study is similar to that of (P. Hakizimana et al. , 2011, P.32) who found that plant resources offer households opportunities to diversify their sources of income, food, energy, various materials and especially the popular pharmacopoeia. The availability of resources depends on the seasons. This study showed that fruits are much more available and consumed in the dry season and leafy vegetables in the rainy season. Thus, J.C. Codjia et al., (2003, P.327) have shown that the availability of resources consumed by populations constitutes a considerable advantage characterized by a food deficit in agricultural products.

The periodic availability of edible plant natural resources helps support household nutrition. The study by G. H. Traoré etal., (2019, P. 112) showed that preferences and knowledge about nutritional values, periodically available species are solicited in daily food rations. S. Hasalkar and V. Jadhav, (2004, P. 205) have also shown that the use of these forest plants contributes in addition to meeting food needs; to supplement the food ration in times of famine and to develop income-regenerating activities. The edible natural plant resources consumed by the populations of Gogounou contain enormous nutritional values, energy etc. through the consumption of the different organs of these resources. Thus, the study by A. J. Agbankpe et al. (2014, p.1784) have 
Vol. 06, No. 06; 2021

ISSN: $2456-8643$

shown that leafy greens are excellent inputs for the diversification of the human diet, hence food security. The results showed that edible mushrooms are resources that are consumed abundantly during the lean season. Similarly, according to S.M. Razafinjatovomalala, (2013, p. 38) local people resort to mushrooms during the period of scarcity. A period is marked on the one hand by the depletion of food reserves and on the other hand by the abundance of edible mushrooms.

\section{CONCLUSION}

The present study on the food security of the populations of Gogounou in Benin: contribution of edible natural plant resources has made it possible to identify several natural plant resources that are consumed. Different organs (leaves, root, fruits, etc.) are consumed by populations. These resources, which contain nutrients, allow the diversification of meals throughout the year. The frequency of consumption of these resources varies from 2 to 4 times a day to a few rare times depending on the social strata of the population. As far as the appreciation of these resources is concerned, they are preferred by more than half of the respondents. But it is clear that despite the contribution of these resources to food security, their conservation and valorization is still very low. It is therefore necessary to conserve leafy resources that are scarce during lean seasons. The conservation of these resources will make it possible to cope with the shortage of food during the period when the cultivated products begin to run out. The orientation ofstudies on the importance and role of edible plant natural resources in food security could lead to the development of policies for the rational and careful use of edible natural plant resources for human consumption. The conservation and enhancement of edible mushrooms in the municipality will make it possible to dispose of mushrooms in full time.

\section{REFERENCES}

Agbankpe Alidéhou Jerrold, Dougnon Tamègnon Vitorien, Bankole Honoré Sourou., Yehouenou Blaise, Yedomonhan Hounnankpon and Legonou Marie, "Ethnobotanical study of therapeutic leafy vegetables used in the treatment of diarrhea in south Benin (West Africa)", International Journal of Biological Chemistry, 8(4): 1784-1795.

Alladayè Fiacre, Mitchikpè Comlan Evariste Simon and Adégbola Patrice Ygué., 2017, "Seasonal variation of nutritional intakes of children aged 24 to 59 months in the agroecological zones of the departments of Borgou and Alibori in north-eastern Benin", Bulletin de la recherche agronomique du Bénin, special issue food technology and food security, INRAB, 4656.

Daudet Adrienne, 2012, Wild Foods and their Ability to Prevent Malnutrition, Action Against Hunger, P. 34

FAO, 2006, Wild Edible Mushrooms, Overview of Their Uses and Importance to Populations, $157 \mathrm{p}$.

FAO, 2006, Management of Natural Resources Supplying Non-Timber Forest Food Products in Central Africa, Study Report Project GCP/RAF/398/GER, 103 p.

Goussanou Cédric., Brice Tente, Djego Julien Gaussanou, Agbani Pierre and Brice Sinsin, 2010, "Inventory, characterization and management mode of some non-timber forest products of the Donga watershed", Annales des Sciences Agronomiques 14 (1) 75-100.

Hasalkar Suma et Jadhav Veena, 2004, «Role of Women in the Use of Non-Timber Forest Produce : A Review », Journal of Socila Sience 8(3): 203-206 
Vol. 06, No. 06; 2021

ISSN: $2456-8643$

Jean Timothée Claude Codjia, Achille Ephrem Assogbadjo and Marius Rodrigue Mensah Ekué, 2003, « Diversité et valorisation au niveau local des ressources végétales forestières alimentaires du Bénin », Cahiers Agricultures 2003, 12, 321-331

Malick Ndiaye and Vam Officer, 2014, Food Security Indicators, World Food Programme, 27 p. Moussa Djibo Ibrahim, Diouf Abdoulaye, Morou Boubé, Adagoye Adamou Boubacar, Agúndez Dolores Maria and Oumani Amadou Abdoulaye, 2020, "Local perception on the state of spontaneous woody species and their role: case of the rural communes of Tamou and Simiri in Niger", Rev. Ivorian. Sci. Technol., 35, 328 - 344.

WFP, 2013, Assessment of Food Security of Rural Households in the Sahelian and Sudanese Zones of Chad, p.40

Pascal Hakizimana, Tatien Masharabu, Frédéric Bangirinama, Bernadette Habonimana and Jan Bogaert, "Analysis of the role of plant biodiversity in the forests of Kigwena and Rumonge in Burundi", Tropicultura, 29, 1, 28-38.

Razafinjatovomalala Sarindranavalona Miora, 2013, "Study of the potentialities of edible mushroom species in the undergrowth of the sclerophyll forest of medium altitude with a view to their valorization: case of the rural commune of Arivonimamo, Itasy region", thesis of the engineering degree in agronomic sciences, University of Antananarivo p.134.

Traoré Gô Hamidou, Sanou Lassina, Koala Jonas, 2019, "Diversity of uses and knowledge of preferred local species in the Forest Corridor of the Boucle du Mouhoun, Burkina Faso", Science and Technology, Natural and Applied Sciences Vol. 38, ${ }^{\circ} 1,101-117$ 